\title{
Erratum to: Development of a PCR Assay for the Rapid Detection and Differentiation of 'Candidatus Liberibacter solanacearum' Haplotypes and Their Spatiotemporal Distribution in the United States
}

\author{
Aimin Wen • Chris Johnson • Neil C. Gudmestad \\ Published online: 20 April 2013 \\ (C) Potato Association of America 2013
}

Erratum to: Am. J. Potato Res.

DOI 10.1007/s12230-012-9293-9

Older versions of Figs. 1, 2, 3 and Tables 1 and 2 were inadvertently published. The updated figures and tables are reproduced here.
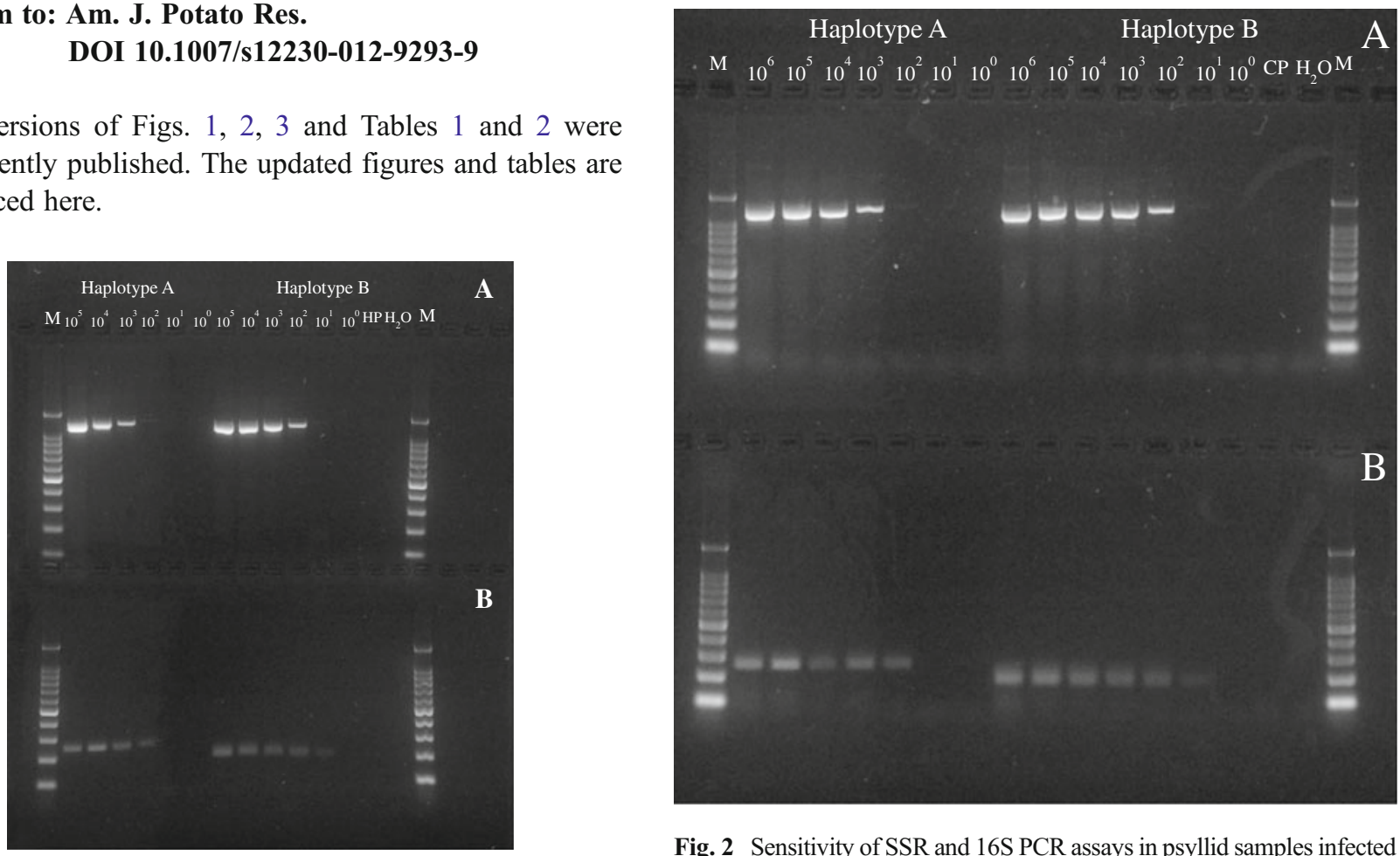

Fig. 1 Sensitivity of SSR and 16S PCR assays in potato samples infected with haplotype A Lso or haplotype B Lso. a 16S PCR products, and b SSR PCR products on the same set of DNA sample dilutions. Lane1-6: 10-fold dilutions of total DNA extracted from potato sample harboring haplotype A Lso with starting $10^{5}$ copies of Lso genome; lane 7-12: 10-fold dilutions of total DNA extracted from potato sample harboring haplotype B Lso with starting $10^{5}$ copies of Lso genome; lane 13: potato DNA sample free of Lso; lane 14: water, negative control. M: 100 bp plus DNA ladder (Qiagen)

The online version of the original article can be found at http://dx.doi.org/ 10.1007/s12230-012-9293-9.

\footnotetext{
A. Wen $\cdot$ C. Johnson • N. C. Gudmestad $(\bowtie)$

Department of Plant Pathology, North Dakota State University,

Fargo, ND 58108, USA

e-mail: neil.gudmestad@ndsu.edu
}

Fig. 2 Sensitivity of SSR and 16S PCR assays in psyllid samples infected with haplotype A or haplotype B Lso. a 16S PCR products, and b SSR PCR products on the same set of sample dilutions. Lane 1-7: 10-fold dilutions of total DNA extracted from psyllid harboring haplotype A Lso with starting $10^{6}$ copies of Lso genome; lane 8-14: 10-fold dilutions of total DNA extracted from psyllid harboring haplotype B Lso with starting $10^{6}$ copies of Lso genome; lane 15: psyllid DNA sample free of Lso; lane 16: water, negative control. M: 100 bp plus DNA ladder (Qiagen) 
Fig. 3 'Candidatus

Liberibacter solanacearum' haplotype detection frequency in potato samples collected in California, Colorado, Nebraska, Texas, Mexico and New

Zealand from 2006 to 2012. a

Texas; b Nebraska; c Colorado; and d All samples tested including those from California, USA and from Mexico and New Zealand
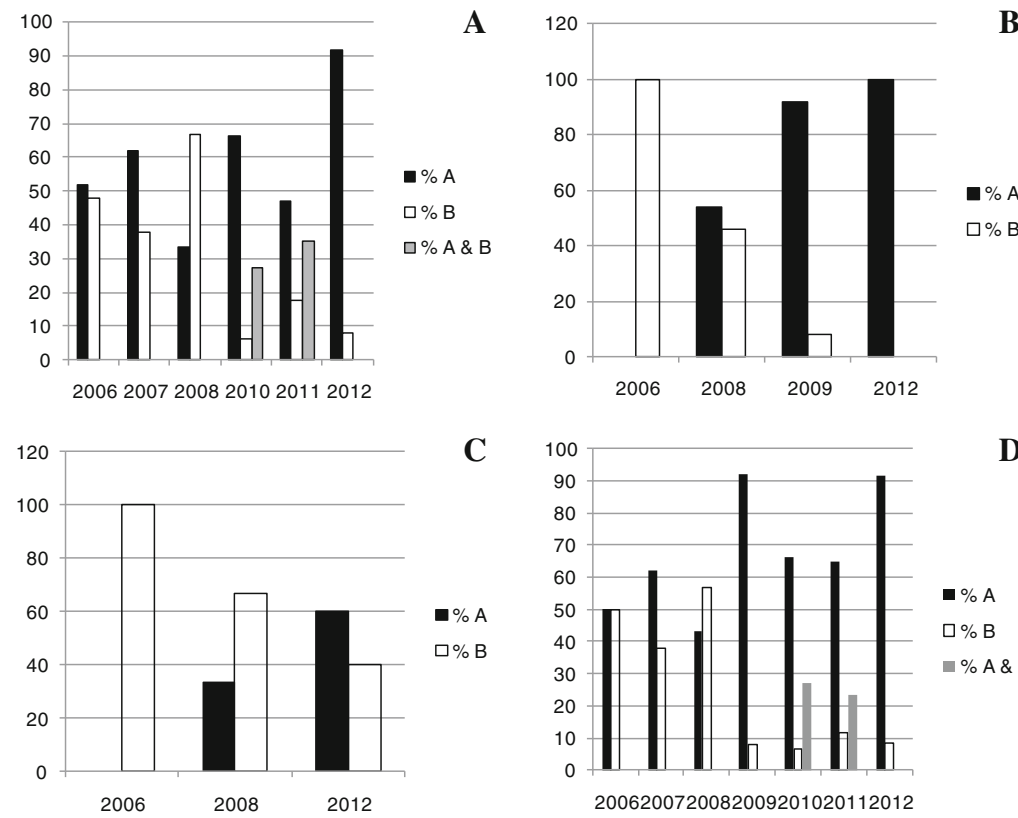

C

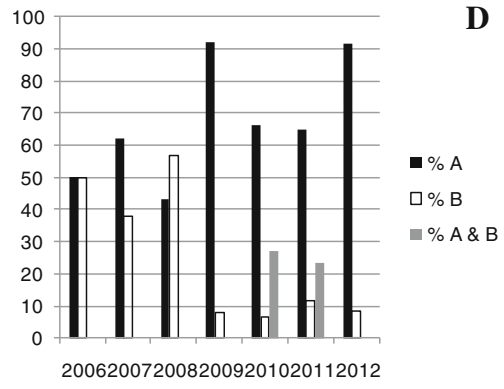

Table 1 Frequency of 'Candidatus Liberibacter solanacearum' haplotypes detected in archived DNA from potato samples obtained from seven states of the USA, New Zealand and Mexico in 2006-2012

\begin{tabular}{|c|c|c|c|c|}
\hline \multirow{2}{*}{$\begin{array}{l}\text { Year of } \\
\text { collection }\end{array}$} & \multirow{2}{*}{$\begin{array}{l}\text { Origin }^{\mathrm{a}} \text { and symptom } \\
\text { (number of samples) }\end{array}$} & \multicolumn{3}{|c|}{$\%$ Lso haplotype } \\
\hline & & A & $\mathrm{B}$ & A \& B \\
\hline \multirow[t]{3}{*}{2006} & CO, ZC (1) & 0 & 100 & 0 \\
\hline & NE, ZC (2) & 0 & 100 & 0 \\
\hline & TX, ZC (73) & 52 & 48 & 0 \\
\hline 2007 & TX, ZC (34) & 62 & 38 & 0 \\
\hline \multirow[t]{8}{*}{2008} & $\mathrm{CO}, \mathrm{ZC}(6)$ & 33 & 67 & 0 \\
\hline & KS, PY (7) & 29 & 71 & 0 \\
\hline & KS, ZC (17) & 29 & 71 & 0 \\
\hline & NE, PY (4) & 100 & 0 & 0 \\
\hline & NE, ZC (25) & 47 & 53 & 0 \\
\hline & TX, PY (6) & 50 & 50 & 0 \\
\hline & TX, ZC (72) & 31 & 69 & 0 \\
\hline & MX, ZC (16) & 100 & 0 & 0 \\
\hline \multirow[t]{2}{*}{2009} & CA, ZC (13) & 92 & 8 & 0 \\
\hline & NE,ZC (62) & 92 & 8 & 0 \\
\hline \multirow[t]{2}{*}{2010} & TX, PY (16) & 93 & 7 & 0 \\
\hline & TX, ZC (110) & 63 & 6 & 31 \\
\hline \multirow[t]{5}{*}{2011} & ID, ZC (77) & 100 & 0 & 0 \\
\hline & TX, PY (79) & 100 & 0 & 0 \\
\hline & TX, ZC (250) & 30 & 23 & 47 \\
\hline & WA, ZC (77) & 100 & 0 & 0 \\
\hline & NZ, ZC (11) & 100 & 0 & 0 \\
\hline \multirow[t]{6}{*}{2012} & $\mathrm{CO}, \mathrm{ZC}(10)$ & 60 & 40 & 0 \\
\hline & ID, ZC (23) & 100 & 0 & 0 \\
\hline & NE, PY (4) & 100 & 0 & 0 \\
\hline & NE, ZC (11) & 100 & 0 & 0 \\
\hline & TX, PY (15) & 100 & 0 & 0 \\
\hline & TX, ZC (30) & 88 & 12 & 0 \\
\hline
\end{tabular}

${ }^{\mathrm{a}} N Z$ stands for New Zealand, $M X$ stands for Mexico

${ }^{\mathrm{b}} Z C$ stands for zebra chip, $P Y$ for psyllid-yellows
Table 2 Frequency of 'Candidatus Liberibacter solanacearum' haplotypes detected in archived DNA from psyllid samples obtained from five states in the USA, New Zealand and Mexico in 2010-2012

\begin{tabular}{lcrrr}
\hline \multirow{2}{*}{$\begin{array}{l}\text { Year of } \\
\text { collection }\end{array}$} & $\begin{array}{l}\text { Origin (number of } \\
\text { Lso positive samples) }\end{array}$ & \multicolumn{3}{c}{ \% Lso haplotype } \\
\cline { 3 - 5 } 2010 & A & B & A \& B \\
\hline & CA (4) & 0 & 100 & 0 \\
& ND (37) & 100 & 0 & 0 \\
& NE (54) & 98 & 2 & 0 \\
2011 & TX (5) & 0 & 100 & 0 \\
& WA (8) & 50 & 37 & 13 \\
& TX (12) & 33 & 25 & 42 \\
2012 & NZ (8) & 100 & 0 & 0 \\
\hline
\end{tabular}

${ }^{\text {a }} \mathrm{NZ}$ stands for New Zealand

${ }^{\mathrm{b}}$ Mexico psyllids were raised in growth room in Moxie, WA 